\title{
Onzekerheid in 2015?
}

Het lijkt alsof er van alle kanten wordt gerammeld aan ons gevoel van veiligheid. We verkeren in onzekerheid of het nog winter wordt, niemand weet of er ooit nog een Elfstedentocht verreden kan worden, evenmin is duidelijk of Zwarte Piet nog terugkeert in ons cultureel landschap. In het afrekenklimaat in de Randstad valt de ene dode na de andere, de politie zit met de handen in het haar, niemand weet of we op deze manier niet alle criminelen kwijt gaan raken. Aan de oostkant van ons landje rukt het geboefte overal op en we hebben geen enkele zekerheid of de Russen onze nieuwe vijanden zijn en straks ook aan onze grens staan. Scoren de strijders voor een islamitische staat hoger op de maten voor het produceren van bestaansonzekerheid, of is dat toch nog Al-Qaeda, of is de grootse vijand Assad? De Syriëgangers komen vroeg of laat via de veel te zwakke buitengrens van Europa ons landje binnenmarcheren en houden ons uit de slaap. De ooit zo veilige vliegtuigen lijken nu wel met bosjes uit de lucht te vallen; kunnen we nog veilig reizen? Aan de westkant van ons fragiele lage landje nemen de stormen toe en blazen het Noordzeewater over onze duinen en dijken. Niemand weet of deze hiertegen bestand blijven; wanneer verdwijnen we weer geheel of ten dele onder water? Ten zuiden van ons land treffen we een ontevreden, verdrietig en stakend volk aan; zouden zij hun frustratie op ons kunnen gaan richten? De verkiezingen in Griekenland bedreigen opnieuw de stabiliteit van de euro en van de EU; het kan maar zo zijn dat dit voorjaar onze euro's en daarna wellicht onze spaarcentjes verder wegsijpelen in een door niemand gekende bodemloze put. De lagelonenlanden sturen onze ondernemers met een enkeltje terug naar huis; gaan wij nu minder verdienen of sturen we de entrepreneurs naar de bijstand? De Chinese economie is groter gegroeid dan die van onze zuster de Verenigde Staten; eten we straks alleen nog Chinees? De werkloosheid waarmee we nog steeds worstelen is tergend en niemand kan voorspellen of het hiermee ooit beter zal gaan; wie doet er echt wat aan? Op alle niveaus blijkt corruptie, machtsmisbruik en persoonlijke verrijking in Nederland veel ernstiger te zijn dan we gewend waren toen we het polderen nog praktiseerden of toen vadertje Den Uyl ons toesprak aan het begin van de oliecrisis. Accountantskantoren schaatsen een scheve schaats, burgemeesters zijn niet meer van onbesproken gedrag, de PvdA gidst ons niet meer door de sociale problemen heen. Op wie kunnen we onze koers nog wel afstemmen? Onze voetbalteams en trainers produceren niets dan onzekerheid over de toekomst. Ons kompas wordt ontregeld door alle door elkaar dansende ICT-technologieën, afwijkende softwaresystemen, niet aan onze wensen tegemoet komende apps. Wie zorgt er voor een herijking? Onze experts op het vlak van kunstmatige intelligentie en ICT werken aan robots die ons - naar verluid - op een IQ-test straks verslaan en vervolgens met ons gaan schuiven zoals met pionnen op een schaakbord.

Alsof de actualiteit al niet genoeg onveiligheid produceert, heeft nu ook een serie sadistische geleerden geopperd dat onze westerse kalender, gebaseerd op de geboorte van Christus, niet klopt. Wellicht is hij enkele jaren eerder op de aarde verschenen en het jaar 0 blijkt nooit te hebben bestaan. Straks ontdekken ze nog dat God niet bestaat, wat moeten we dan? Het is zelfs niet meer boven elke twijfel verheven dat het glas rode wijn dat we tijdens de feestdagen dronken ons in 2015 nog beschermt tegen hart- en vaatziektes. De vrije keuze van de GZ-psycholoog en arts staat op de tocht. Of de gemeentes hun geld echt aan de jeugdzorg besteden is nog maar helemaal de vraag.

Maar ik blijf dol op feiten, en wat echt vaststaat is dat wij westerlingen in de veiligste, meest stabiele, meest zekere en gelukkigste tijd leven die de mensheid ooit heeft gekend. Of we ontregeld raken door bovenstaande gebeurtenissen, die geen enkele echte inbreuk op ons leven doen, heeft voor de GZ-psycholoog in de psychologische kern te maken met hoeveel onveiligheid we in de vroegkinderlijke gehechtheid te verduren hebben gekregen. Indien de gehechtheidrelatie plaatsvond met een responsieve ouder of verzorger trek je je van al het bovenstaande bitter weinig aan en help je degenen die er wel last van hebben. Voor hulp bij de psychische realiteit staan ook in 2015 weer meer dan 15.000 collega's klaar. Zoveel zijn het er nog nooit geweest. Alle kans op een veilig 2015 .

Prof. dr. J.J.L. Derksen is klinisch psycholoog en hoofdredacteur van GZ-Psychologie. 